\title{
Theoretical Antibiotic Selection for the Polymicrobial Infection of Crohn's Disease
}

\author{
Gilles RG Monif* \\ Infectious Diseases Incorporated, USA
}

Submission: February 03, 2018; Published: August 24, 2018

"Corresponding author: Gilles RG Monif, Infectious Diseases Incorporated, 17121 Lakewood Drive Bellevue Nebraska 68123, USA, Tel: 01-492-618-0963; Email: gmonif@AOL.com

Abstract

The management of polymicrobial infection within Crohn's disease is deemed to require

a) Rapid re-establishment of mucosal integrity and

b) Valid four category coverage within the Gainesville Classification until access to the gastrointestinal microbiota is terminated.

Crohn's disease is the product of two independent, but inter-related, infectious disease processes that co-function over time:

i. An immune-mediated disease initiated and perpetuated by Mycobacterium avium subspecies paratuberculosis (MAP) and

ii. Polymicrobial infection derived from tissue invasion by the gastrointestinal microbiota.

The antimicrobial mandates of each of these entities differ significantly.

Keywords: Immune-mediated disease; Crohn's disease; Microbiota; Polymicrobial infection

\section{Mini Review}

\section{MAP's Immune-mediated disease process}

The therapeutic objective for the immune-mediated component of Crohn's disease is destruction of the MAP template that drives the dysfunctional response to MAP at its points of attachment and antigen processing. Post-initial infection, MAP resides in the human body in its spheroclastic form. To destroy the MAP template, antimicrobial therapy needs to utilize compounds whose mechanisms of action disrupts either 20 s or $50 \mathrm{~s}$ ribosome function.

\section{Polymicrobial Infectious from the Gastrointestinal Microbiota}

Immune-mediated focal destruction of the ileocecal mucosa establishes an open portal for invasion by constituents of the microbial flora of the gastrointestinal tract. For the resultant polymicrobial bacterial component, it is argued that antimicrobial therapy needs to focus on eradication of the constituents within anaerobic progression.

Gorbach \& Bartlett [1] have described the dynamic transformation that occurs when infection has open access to a complex bacterial flora. The theoretical basis for their "the anaerobic progression" had a real-world documentation by the demonstration that, given open access to a microbial flora, monomicrobial disease due to Neisseria gonorreahoeae could convert to a polymicrobial disease that then followed the dictates of the anaerobic progression [2]. In 1982, documentation that, given open access to female genital tract flora, polymicrobial infection could evolve from nonetiological disease, ultimately obligated the Centers for Disease Control and Prevention to radically revise its therapeutic recommendation for the treatment of gonococcal disease in women [3].

To guide antibiotic selection for polymicrobial diseases within the disciplines of Obstetrics and Gynecology, a schema for antibiotic selection, based on selected bacterial groupings within polymicrobial infections of the female genital tract, the Gainesville Classification was constructed [4].

Confronted with potential life-threating consequences, the Gainesville Classification demands comprehensive coverage of the bacteria within each of its four categories. In polymicrobial infection, a gap in category coverage can reset bacterial replication dominance. 
The Gainesville Classification identifies four broad categories within polymicrobial infections that need to be eradicated if continued tissue damage is to be terminated:

a) Category I. Both facultative anaerobic and anaerobic gram-positive bacteria.

b) Category II. The enterococci

c) Category III. The Bacteroidiaceae and gram-negative obligatory anaerobes

d) Category IV. The facultative anaerobic gram negative Enterobacteriaceae

\section{The Status Quo for Antibiotic Selection in Crohn's Disease}

In Crohn's disease, sustained, localized destruction of the lining epithelium and the resultant loss of mucosal integrity allow for establishment of a polymicrobial infection. Confronted with markers of inflammation or clinical evidence of infection, gastroenterologists had turned a combination of ciprofloxin and metronidazole.

\section{Metronidazole}

Within the Gainesville Classification, metronidazole basically lock-down coverage for the anaerobic gram-positive cocci (the obligatory anaerobic component of Category I and the Bacteroidiaceae and other gram-negative obligatory anaerobes (Category III).

\section{Ciprofloxacin}

In theory, Ciprofloxin provided coverage for the aerobic Gram-positive cocci (Categories I and II) as well as some of the Enterobacteriaceae (Category IV). Ciprofloxin provides incomplete spectrum coverage, for both the Enterobacteriaceae and the enterococci. Ciprofloxacin utilization over time has selected for increasing bacterial resistance to the drug.

\section{Enterobacteriaceae}

The Enterobacteriaceae and facultative anaerobic grampositive cocci tend to be early contributors to the gastrointestinal pathology of Crohn's disease. The hallmark of inadequate therapy for the Enterobacteriaceae is healing by fibrosis. The location of fibrosis and the amount of fibrosis time-stamp the interim in which a member of the Enterobacteriaceae dominated within the polymicrobial infection. The ultimate destructive realm of the Enterobacteriaceae is limited by the bacterial re-prioritization within the anaerobic progression.

\section{Enterococci}

With the anaerobic progression, the enterococci function neither as a premier aerobic nor anaerobic pathogen. Their ability to replicate over a significant range of environmental conditions makes the enterococci an important group of bacteria in transitioning the conditions for bacterial replication from facultative to obligatory anaerobic. The enterococci are one of the last organisms to be eliminated before the requisite for being an obligatory pathogen is imposed. Given the importance of the enterococci (Category II) in the anaerobic progression, ciprofloxin is a less than optimal choice.

The gastrointestinal tract has a remarkable ability to deal with bacterial invasion. Once mucosal integrity is re-established, undertreated or untreated infection dies out, but at a price. Maximum fecal stasis dictates the sites of immune-mediated destruction of small bowel mucosa. With polymicrobial infection re-occurring at a future date in basically the same region, the anatomical structural changes imposed by prior infection increase the probability of local acceleration of the anaerobic progression within future challenges.

Once the conditions for abscess formation are achieved, the intra-abscess penetration by antibiotics becomes limited. The amount of antibiotic that does arrive is subjected to secondary inactivation. Abscess formation within the muscularis ultimately translates to loop-to -loop fistula. The creation of loop-toloop abscesses is the obligatory anaerobic component of the anaerobic progression reaching the underlying serosal surface, and through inflammatory bonding, invading adjacent bowel.

It is argued that management of polymicrobial infection within Crohn's disease requires

i. Rapid re-establishment of mucosal integrity and

ii. Valid four category coverage until closure to the gastrointestinal microbiota is achieved.

\section{References}

1. Gorbach SL, Bartlett JG (1974) Anaerobic infections. N Engl J Med 290: 1280-1294.

2. Monif GRG (1980) Significance of polymicrobial bacterial superinfection in the therapy of gonococcal endometritis-salpingitisperitonitis. Obstet Gynecol 55(5): 154s-161s.

3. Monif GRG (2008) Acute Sapingitis in Infectious Diseases in Obstetrics and Gynecology. (6 ${ }^{\text {th }}$ edn), Informa, London, pp 451-468.

4. Monif GRG Infectious Diseases in Obstetrics and Gynecology, ( $6^{\text {th }}$ edn $)$, Informa, London England, pp.12-23. 
This work is licensed under Creative Commons Attribution 4.0 License DOI: 10.19080/ARGH.2018.10.555785

\section{Your next submission with JuniperPublishers} will reach you the below assets

- Quality Editorial service

- Swift Peer Review

- Reprints availability

- E-prints Service

- Manuscript Podcast for convenient understanding

- Global attainment for your research

- Manuscript accessibility in different formats

( Pdf, E-pub, Full Text, audio)

- Unceasing customer service

Track the below URL for one-step submission https://juniperpublishers.com/online-submission.php 